\title{
LIST OF REFEREES
}

The editorial committee wishes to thank the referees.

- Veronica Baxter

Drama Department, University of Cape Town, South Africa

Amelda Brand

Applied Theatre, University of Stellenbosch, South Africa

- Ashwanee Budoo

Centre for Human Rights, University of Pretoria, South Africa

- Antoon De Schryver

Department of Social Medicine, University of Antwerp, Belgium

- James Lees

Faculty of Education and HIV \& AIDS Programme, University of the Western Cape, South Africa

- Caroline Masquillier

Department of Sociology, University of Antwerp, Belgium

- Sophie Mew

Anthropology Department, The Horniman Museum, United Kingdom

- Didier Jean Benoit Michel

Department of Law, University of Mauritius, Mauritius

- Marie Valerie Uppiah

Department of Law, Faculty of Law and Management, University of Mauritius, Mauritius

- Hannelore Vandenbergen

Department of Languages and Cultures, Ghent University, Belgium

- Annelies Verdoolaege

Department of Languages and Cultures, Ghent University, Belgium

- Matthias Warstat

Institut für Theaterwissenschaft, Freie Universität Berlin, Germany 